\title{
Women Engineers in Entrepreneurship: An Alternative Pathway
}

\section{Mrs. Lesley Cremeans, Texas Tech University}

PhD student in Higher Education Research and instructor in the Department of Physics \& Astronomy at Texas Tech University.

\section{Dr. Audra N. Morse P.E., Texas Tech University}

Dr. Audra Morse, P.E., is a Professor in the Department of Civil, Environmental, and Construction Engineering at Texas Tech University. Her professional experience is focused on water and wastewater treatment, specifically water reclamation systems, membrane filtration and the fate of personal products in treatment systems. However, she has a passion to tackle diversity and inclusion issues for students and faculty in institutions of higher education. 
Women Engineers in Entrepreneurship $\left(\mathrm{WE}^{2}\right)$ : An Alternative Pathway 


\section{Introduction}

The majority of the population in the United States (US) are women, 50.7\% (United States Census Bureau, 2014). Women earn more overall undergraduate degrees than men, yet remain underrepresented in science, technology, engineering, and mathematics (STEM) undergraduate degrees and workforce (NSF, NCSES, 2015). Women represent a total of $31.7 \%$ in the engineering workforce as engineers $(12.9 \%)$ and engineering and related technologist or technician (18.8\%, NSF, NCSES, 2015). Engineering professions require significant academic training in math and scientific concepts (Hill, Corbett, \& St. Rose, 2010) and studies show women are as capable as men in math and science content knowledge.

The gender disparity in engineering professions are commonly associated with negative psychological (self-efficacy and self-confidence), environmental (chilly climate), and societal gender stereotypes (Balakrishnan \& Low, 2016; Bandura, 1977a; Hill et al., 2010). Engineering is historically male-dominated and constructed as masculine. Occupational organizations, including engineering educational institutions and workplaces often operate in the context of gender frames, or assumptions about what it means to be a male or female engineer (Ridgeway, 2009). Women engineers must often create an identity independent from the gender frames that construct engineering as masculine. The masculine aspects of engineering further increase the gender disparity in the workforce by categorizing a "real engineer" based on stereotypical gender norms.

"Who am I?" is a question that seeks to identify a person's definition of one's self, or identity. Identity research is 'the study of a certain 'kind of person,' where individuals have multiple identities that are related to their social performances rather than purely to their unique being" (Hazari, Sadler, Sonnert, 2013, p. 82). The paper will explore the literature on identity formation of female students in engineering and summarize external data on the impacts of entrepreneurship education and real-world application on identity formation.

\section{Social Identity Theory (SIT)}

According to Hogg and Abrams (1988), a social identity is an individual's knowledge of belonging to a social category or group. A social group is "a set of individuals who hold a common social identification or view themselves as members of the same social category" (Stets $\&$ Burke, 2000, p. 225). There are two important processes involved in social identity formation: self-categorization and social comparison (Hoggs \& Abrams, 1988; Stets \& Burke, 2000). Selfcategorization is a comparison between a person's self and others' "attitudes, beliefs and values, affective reactions, behavioral norms, and styles of speech" (Stets \& Burke, 2000, p. 224). Social comparison is the act of evaluating social groups negatively or positively based on personal selfesteem benefits.

Identification with a social group in which individuals share certain traits, attitudes and behaviors is called a collective identity (Ashmore, Deaux \& McLaughlin-Volpe, 2004). Stets and Burke (2000), assert individuals are born into a structured society and derive identities from a combination of social categories. Gender is a background identity that shapes collective identities, thus creating expectations through a prism of gender. Gender/sex "is a form of human 
variation that is highly susceptible to cultural generalization as a primary category for framing social relations" (Ridgeway, 2009, p. 148). Gender frames define differences among people. Gender frames shape institutional practices that define efforts as masculine/feminine and the relative value of expectations. Engineering is labeled as traditionally male-dominated and gender is often used to divide men and women to maintain a masculine identity. Women must face the dilemma of meeting gender norms while simultaneously being presented as "real" engineers, based on the masculine aspects of engineering.

\section{Identity Theory}

Similar to SIT, identity theory focuses on the components of a structured society (Stets \& Burke, 2000), but identity formation occurs based on a relationship of designated positions or roles in society (Stryker, 1980). The acceptance of membership into a role shapes the identity of an individual (i.e. professor, student, engineer). Adopting an identity as a female engineer means that women are challenging the social expectations for women and men.

Engineering degrees tend to be awarded to more females in chemical, materials, industrial and civil engineering (NSF, NCSES, 2015). Research shows females tend to follow engineering paths that incorporate interpersonal and communal goals (e.g., helping others, working with people) with traditional industry goals (Hazari, Sadler, \& Sonnert, 2013). The perception of the alternative engineering career options does not appear to include opportunities to achieve interpersonal or communal goals (Hazari et al., 2013). Women's reluctance to earn degrees in other fields of engineering can be attributed to "the lack of consistent information regarding the nature of work done by engineer's" (Dzombak et al., 2016, p. 4) which leads to a general misunderstanding of the engineering profession.

\section{Female Engineering Identity}

Science identity is defined as the individual's perception of science "related to who they think they are" (Brickhouse, Lowery, \& Schultz, 2000, p. 443). A limitation to research on women in engineering is formally defining engineering identity in the research. Engineering identity formation is a concept drawn from science identity formation with a focus in engineering (Pantoya, Aguirre-Munoz, \& Hunt, 2015).

Learning experiences serve as a primary reason that females pursue engineering academic disciplines and careers (Balakrishnan \& Low, 2016). Learning experiences and environments can influence the engineering identity of the female student (Balakrishnan \& Low, 2016; Chachra, Kilgore, Loshbaugh, McCain, \& Chen, 2008). A challenge of identity formation for female engineers is to balance the devaluing that occurs through rhetoric (Kyriakidou, 2011). Behaviors in the workplace and the classroom can create a chilly climate for females. The creation of a "boys club" workplace or classroom devalues the presence of women in engineering (Miller, 2004; Walker, 2001).

Women use a variety of strategies to minimize this devaluation including reducing the perceived salience of their gender and emphasizing to others their identities as engineers, without the potentially devaluating tag of "female" engineer (Van den Brink \& Stobbe, 2009; Walker, 2001). 
Women try to cope by being "one of the boys" - accepting discrimination, building a strong reputation as an engineer and becoming anti-woman (Powell, Bagilhole \& Dainty, 2009).

Faulkner (2007) found that as women increase participation in the engineering field, there is an increased effort to define aspects of engineering as masculine or feminine for placing value on areas of engineering. Areas are classified as hard versus soft engineering (Faulkner, 2007) and imaginary versus real (Foor \& Walden, 2009). Engineering is constructed as masculine, and women must create an identity independent from the gender frames that construct engineering as belonging to men. This has been accomplished by an increasing tendency to preserve the masculine hegemony in engineering by redefining different engineering tasks and skills as masculine or feminine.

\section{Entrepreneurship education}

Entrepreneurship pathways to engineering professions change the rules for females in a chilly, male-dominated industry. Technology and engineering entrepreneurship programs equip students with knowledge and skills in a new economic environment (Duval-Couetil, Shartrand, \& Reed, 2016). Entrepreneurship education is most affective when it includes an experiential component - a component that requires intellectual and physical engagement — during the learning process. Experiential learning components (i.e. business plan development, startups, consultations and interviews with entrepreneur professionals, environmental scans, field trips, phone app developments) differ based on proposed models of entrepreneurship education (Duval-Couetil et al., 2016).

According to Cromie (1987), females are motivated by "achievement, autonomy, enhanced job satisfaction, and the desire to make money" (p. 253). Many of the retention issues with females in engineering occupations are centralized on promotional opportunities, inequality in pay, isolation, inability to balance family and work life, and negative gender stereotypes associated with the traditional culture of engineering programs (Balakrishnan \& Low, 2016; Cromie, 1987; Dzombak et al., 2016; \& Hill et al., 2010). The independent nature of entrepreneurial business provides women more control over their work circumstances and therefore provides them a chance to overcome many of the gender-based problems that women face in engineering.

The field of entrepreneurship can be viewed as feminine through a gender frame based on the aspects of the job rather than the job itself. Entrepreneurship fits into the "feminine side in engineering" because it is a heterogeneous pursuit that involves not only the technical aspects of the creation of products and technology but it involves the diversity of skills that are associated with the feminine aspect of engineering. Gender stereotypes surrounding the skills of an engineer create a division between women and men in classrooms and industry. In reality, women and men can successfully accomplish "feminine" and "masculine" tasks that define an engineer.

The entrepreneurship literature discusses specific characteristics - desire for achievement, innovativeness, and independence - that male and female entrepreneurs have in common (Tan, 2008). To achieve success, however, the individual must have a clear focus on their future professional aspirations (Tan, 2008). According to Dzombak et al. (2016), engineers are 
considered to be "naturally skilled at innovation" (p.6) and engaging in entrepreneurial ventures enriches educational experiences. Entrepreneurial experiences can theoretically enhance the learning experience of the student and according to Balakrishnan and Low (2016) a positive learning experience can impact the engineering identity of students and help retain underrepresented populations.

\section{Changing Engineering}

University engineering programs are incorporating engineering entrepreneurship education either through engineering or collaborative (i.e., engineering-business) partnerships. However, social science studies on identity formation needs to be further explored. For instance, Duval-Couetil, Reed-Rhoads, and Haghighi, (2012) highlight the benefits of engineering entrepreneurship education on student self-efficacy and emphasize the need for motivational factors. Entrepreneurship education is believed to compliment engineering education (Duval-Couetil et al., 2012).

The economy and workforce needs are pushing more engineering schools to consider incorporating entrepreneurship education for students (Duval-Couetil et al., 2012; Duval-Couetil et al., 2016). According to Duval et al. (2012), most engineering students recognized the importance of entrepreneurship education and entrepreneurship as a "worthwhile career option" (p. 429). Students with entrepreneurial experiences chose "satisfying a need in a market" as a top reason for entering an entrepreneurship career (Duval-Couetil et al., 2012). Students with entrepreneurship experiences ranked higher in self-efficacy and confidence per the student's perspective of entrepreneurial ability.

Further, the National Science Foundation Innovation Corps (I-Corps) program "prepares scientists and engineers to extend their focus beyond the laboratory" (NSF, I-Corps, 2012). NSF's I-Corps seeks to foster entrepreneurship through a customer and business model development to advance the commercialization of technology. The NSF's strategic plan for the 2011-2016 fiscal years (FY) is to focus on empowering the nation through discovery and innovation (NSF, I-Corps, 2012). The NSF I-Corps aims to develop and nurture innovation ecosystems through three specific components: 1) Teams, 2) Nodes, and 3) Sites. I-Corps Teams is the technical, entrepreneurial, and business education needed to launch innovations. I-Corps Nodes gather, analyze, evaluate, and utilize data to enhance our nation's innovation capacity through education, infrastructure, and research that will benefit society. I-Corp Sites aim to nurture and support teams to transition the concepts into the marketplace (NSF, I-Corps, 2012). I-Corps Sites share the principles of the I-Corps Curriculum and the teams at each site are modeled after the composition of I-Corps Teams (NSF, I-Corps, 2012). Start-ups founded by participants are the main vehicle for commercialization activities, and the projects will be prepared for business formation.

NSF recognizes that the transitioning of technologies out of an academic laboratory requires skill sets and knowledge that differ from those necessary for basic research. NSF's I-Corps program will develop entrepreneurial skills and knowledge in the new generation of scientists and 
engineers. An innovative ecosystem will develop if NSF's past, current, and future research and programs continue to foster innovation and discovery in science and engineer (S\&E) academics.

Moreover, the National Academy of Engineering (NAE) released the publication, "Changing the Conversation" in 2011 to strongly encourage engineering communities to alter the messaging presented to underrepresented populations to increase and attract more diversity (NAE, 2011). According to Dzombak et al. (2016), the NAE describes the work of an engineer as, "Engineers make a world of difference, are creative problem-solvers, help shape the future, connect science to the real world, and engineering is essential to health, happiness, and safety" (p. 5).

\section{Broader Impacts of Entrepreneurship Education}

Entrepreneurship education provides students with skills and knowledge to broaden the application of entrepreneurial skills to many disciplines. Social sciences, arts and humanities, and additional STEM departments are beneficial to the development of innovation and technology. Interdisciplinary partnerships and research could likely emerge from the collaboration between disciplines that study human relationships and organizations.

Entrepreneurship may affect the understanding that educators, students, professional engineers and the business community have of the potential application of entrepreneurship to promoting new ideas and new ways of doing things. Entrepreneurial skills and knowledge can be taught and cultivated to tailor academic and community needs. The promotion of entrepreneurial education in engineering can enhance students' academic experiences and future career aspirations.

Entrepreneurship education can reshape the experiences of women in engineering by allowing them to create a friendlier work environment as leaders and participants in female-only entrepreneurial projects. Unfortunately, women still face a hostile climate in many maledominated fields, including engineering (Lent, Brown, Sheu, Schmidt, Brenner, Gloster, Wilkins, Schmidt, Lyons, \& Treistman, 2005; Holland, Major, \& Orvis, 2011;

Murray, Meinholdt, \& Bergmann, 1999). The field of entrepreneurship can encourage women to create their own new ventures, which will allow them to more easily shape workplace climate, monitor and control the impact of implicit biases and provide a clearer path for success.

\section{Conclusion}

Women continue to remain highly underrepresented in the engineering industries and workforce. The purpose of this paper is to present an alternative career pathway for females in engineering through entrepreneurship to decrease the gender gap in a traditionally, male-dominated industry, engineering. Entrepreneurship experiences increase knowledge and skills. For females specifically, entrepreneurship experiences are beneficial for self-efficacy and confidence. The retention of females in the engineering fields is imperative to the future of our society and economy. Engineers create solutions to problems or issues and the perspectives of both males and females are needed.

\section{References}


Ashmore, R., Deaux, K., \& McLaughlin-Volpe, T. (2004). An organizing framework for collective identity: Articulation and significance of multidimensionality. Psychological Bulletin, 130, 80-114. doi:10.1037/0033-2909.130.1.80

Balakrishnan, B. \& Low, F.S. (2016). Learning experience and socio-cultural influences on female engineering students' perspectives on engineering courses and careers. Minerva, 54(2), 219-239.

Bandura, A. (1977). Sel-efficacy: Toward a unifying theory of behavioral change. Psychological Review, 84(2), 191-215.

Brickhouse, N.W., Lowery, P., \& Shultz, K. (2000). What kind of girl does science? The construction of school identities. Journal of Research in science teaching, 37(5), 441458.

Chachra, D., Kilgore D., Loshbaugh, H., McCain, J. \& Chen, H. (2008). Being and becoming: gender and identity formation of engineering students. ASEE Conference.

Cromie, S. (1987). Motivations of aspiring male and female entrepreneurs. Journal of Organizational Behavior, 8(3), 251-261.

Duval-Couetil, N., Reed-Rhoads, T. and Haghighi, S. (2012). Engineering students and entrepreneurship education: Involvement, attitudes and outcomes. International Journal of Engineering Education, 28(2), 425-435.

Duval-Couetil, N., Shartrand, A., \& Reed, T. (2016). The role of entrepreneurship program models and experiential activities on engineering student outcomes. Advances in Engineer Education, 5(1), 1-27.

Dzombak, R., Mouakkad, S., \& Mehta, K. (2016). Motivations of women participating in a technology-based social entrepreneurship program. Advances in Engineering Education, $5(1), 1-28$.

Faulkner, W. (2007). 'Nuts and bolts and people': Genered-troubled engineering identities. Social Studies of Science, 37(3), 331-356.

Foor, C.E. \& Walden, S.E. (2009). "Imaginary engineering" or "re-imagined engineering": Negotiating Gendered Identities in the borderland of a college of engineering. NWSA Journal, 21(2), 41-64.

Hazari, Z., Sadler, P. M., \& Sonnert, G. (2013). The science identity of college students: exploring the intersection of gender, race, and ethnicity. Journal of College Science Teaching, 42(5), 82-91.

Hill, C., Corbett, C., \& St. Rose, A. (2010). Why so few women? Women in science, technology, engineering, and mathematics. Washington, D.C.: AAUW. 
Holland, J.M., Major, D.A., \& Orvis, K.A. (2011). Understanding how peer mentoring and capitalization link STEM students to their majors. The Career Development Quarterly, 60, 343-354.

Kyriakidou, O. (2011). Negotiating gendered identities through the process of identity construction. Equality, Diversity and Inclusion, 31(1), 27-42.

Miller, G.E. (2004). Frontier masculinity in the oil industry: The experiences of women engineers. Gender, Work and Organization, 11(1), 47-73.

Murray, S.L., Meinholdt, C., \& Bergmann, L.S. (1999). Addressing gender issues in the engineering classroom. Feminist Teacher, 12(3), 169-183.

National Science Foundation, National Center for Science and Engineering Statistics. (2015). Women, minorities, and persons with disabilities in science and engineering: 2015. Retrieved from http://www.nsf.gov/statistics/wmpd/

National Science Foundation. (2012). NSF Innovation Corps (I-Corps). Retrieved from http://www.nsf.gov/news/special_reports/i-corps/

Pantoya, M.L., Aguirre-Munoz, Z., Hunt, E.M. (2015). Developing an engineering identity in early childhood. American Journal of Engineering Education, 6(2), 61-68.

Powell, A., Bagilhole, B., \& Dainty, A. (2009). How women engineers "do" and "un-do" gender: Consequences for gender equality. Gender, Work and Organization, 16(4), 411-428.

Stets, J.E. \& Burke, P.J. (2000). Identity theory and social identity theory. Social Psychology Quarterly, 63(3), 224-237.

Stryker, S. (1980). Symbolic interactionism: A social structural version. Menlo Park, CA: Benjamin Cummings.

Tan, J. (2008). Breaking the "Bamboo Curtain" and the "Glass Ceiling": The experience of women entrepreneurs in high-tech industries in an emerging market. Journal of Business Ethics, 80(3), 547-564.

Walker, M. (2001). Engineering identities. British Journal of Sociology of Education, 22(1), 7589.

United States Census Bureau. (2014, December). Retrieved January 29, 2017, from http://www.census.gov/population/projections/data/national/2014/summarytables.html

Van den Brink, M. \& Stobbe, L. (2009). Doing gender in academic education: The paradox of visibility. Gender, Work and Organization, 16(4), 451-470.

Vest, C.M. (2011). The image problem for engineering: An overview. The Bridge: National Academy of Engineering, 41(2), 5-12. 